\title{
Shoreline Response to a Sequence of Typhoon and Monsoon Events
}

\author{
Rafael Almar ${ }^{1, *}$, Patrick Marchesiello ${ }^{1}$, Luis Pedro Almeida ${ }^{1}$, Duong Hai Thuan ${ }^{1,2}$, \\ Hitoshi Tanaka ${ }^{3}$ and Nguyen Trung Viet ${ }^{2}$ \\ 1 LEGOS (Université de Toulouse/CNRS/CNES/IRD), 31400 Toulouse, France; \\ Patrick.Marchesiello@legos.obs-mip.fr (P.M.); luis.pedro.almeida@legos.obs-mip.fr (L.P.A.); \\ duonghaithuan@tlu.edu.vn (D.H.T.) \\ 2 Faculty of Marine and Coastal Engineering, Thuyloi University, Hanoi, Vietnam; \\ nguyentrungviet@tlu.edu.vn \\ 3 Department of Civil and Environmental Engineering, Tohoku University, Sendai 980-8576, Japan; \\ hitoshi.tanaka.b7@tohoku.ac.jp \\ * Correspondence: rafael.almar@ird.fr; Tel.: +33-05-6133-3006
}

Academic Editor: Maurizio Barbieri

Received: 11 April 2017; Accepted: 18 May 2017; Published: 23 May 2017

\begin{abstract}
Shoreline continuously adapts to changing multi-scale wave forcing. This study investigates the shoreline evolution of tropical beaches exposed to monsoon events and storms with a case study in Vietnam, facing the South China Sea, over the particularly active 2013-2014 season, including the Cat-5 Haiyan typhoon. Our continuous video observations show for the first time that long-lasting monsoon events have more persistent impact (longer beach recovery phase) than typhoons. Using a shoreline equilibrium model, we estimate that the seasonal shoreline behavior is driven by the envelope of intra-seasonal events rather than monthly-averaged waves. Finally, the study suggests that the interplay between intra-seasonal event intensity and duration on the one hand and recovery conditions on the other might be of key significance. Their evolution in a variable or changing climate should be considered.
\end{abstract}

Keywords: Vietnam; South China Sea; erosion; recovery; storminess; winter monsoon; typhoons

\section{Introduction}

It would be a mistake to consider the vulnerability of coastal regions as a simple response to sea level change, assuming static coastal morphology [1,2]. On the contrary, coastal morphology is in a constant process of equilibration at various timescales. It is generally assumed that waves are the main driver of coastal evolution but their role is strongly non-linear, and the coastal response to unsteady forcing is unclear [3].

Beach recovery to extreme events is also still debated as there is not even agreement on their transient or persistent impacts [4,5]. For isolated events, departure from equilibrium is related to the event's intensity and duration $[2,6,7]$. However, no clear conclusion can be drawn when considering a sequence of events, since both enhanced [8] and weakened effects are observed [9-11], e.g., during the particularly stormy winter of 2013-2014 in Europe, e.g., [12]. The timescales' interplay between recurring events and recovery conditions appears determinant.

Existing shoreline equilibrium models (among others: $[2,13,14]$ ) show appreciable skills in predicting shoreline location from wave energy at monthly or longer time-scales for mid-latitude, storm-dominated coasts. However, these skills may be at fault in a so-called low-energy environment as often encountered in the tropics. There, the beach is mostly active during occasional events and is generally found in equilibrium with the preceding energetic event rather than current conditions [15]. 
Existing equilibrium models might not be able to describe such behavior, in particular when energetic wave events do not occur concomitantly with the seasonal peak of wave energy.

Tropical beaches are exposed to infrequent short (1-3 days) but paroxysmal storms such as cyclones (typhoons in the western Pacific) and can rapidly adapt to these very energetic conditions [16]. They slowly recover under persisting low to moderate waves during the rest of the year. However, all the tropical environments are not strictly low-energy, and this is particularly true in Southeast Asia as it is affected by monsoons [17]. Typical winter monsoon events last from three days to three weeks and can bring strong persistent swells of somewhat lower energy but longer duration than tropical storms. There is substantial literature on the atmospheric cold intrusion affecting the Southeast Asian coastal states every winter, e.g., [18] but the role of these energetic events on shoreline evolution has not been investigated. Clearly, they are active processes for shoreline erosion and must be compared with the effect of short-term storms. Their particularly long duration may be a crucial element of their beach response as the beach may have sufficient time to adjust to the energetic conditions and reach equilibrium.

In this paper, we investigate the video-derived shoreline evolution of Nha Trang beach, Vietnam, over the particularly active 2013-2014 season, with numerous winter monsoon events and storms, including the Cat-5 Haiyan typhoon. We first investigate the role of monsoon events on shoreline evolution compared with storms, and secondly the seasonal behavior of the beach in response to both monthly-averaged wave forcing and wave events using a shoreline equilibrium model [2].

\section{Study Site}

Nha Trang is an embayed beach located in southeastern Vietnam coast, facing the South China Sea (Figure 1, upper panel). This $6 \mathrm{~km}$ bay is oriented north-south and is partially sheltered from waves by a group of islands at its southern end. This medium-sized $\left(D_{50}=0.4 \mathrm{~mm}\right)$ sandy beach is rather uniform along the shore, and is characterized by a steep (slope $\sim 0.1$ ) upper face and a flat low-tide terrace $(\sim 40 \mathrm{~m}$ wide). The tide is a mix of diurnal and semi-diurnal, with a small tidal range $(<1.6 \mathrm{~m})$.

\subsection{Typhoons}

The Northwest Pacific is the most cyclogenetic region on earth. Of the 16 tropical storms that turn into typhoons (JTWC 2013) annually, about one-third propagate westward to South China Sea [19]. Every year, 4-6 typhoons hit Vietnam [20], typically between August and December, but the risk of landfall varies strongly at seasonal and interannual scales, e.g., [19,21]. The year 2013 came after two years of La Niña conditions, resulting in strong sea surface temperatures, which favored cyclone generation [22]. As a consequence, 2013 was observed to be the most active typhoon season since 2004, and the one with most casualties since 1975. Among the 10 typhoons landing in Vietnam in 2013, Cat. 5 Haiyan in early November turned into one of the world strongest recorded tropical cyclones [23].

\subsection{Monsoons}

Summer monsoons (May to September) drive relatively weak, short-period southwesterly waves in the South China Sea. The inception of winter monsoon (October to April), caused by high-pressure systems in Siberia, drives strong northeast winds. Because these pressure systems form every three days to three weeks, wind pulses occur at these timescales. As a result, the winter monsoon generates energetic waves larger than $2.5 \mathrm{~m}$ off the Vietnamese coast [24], reaching values up to $4 \mathrm{~m}$, which stands for the $10 \%$ exceedance level of wave climate [25]. 

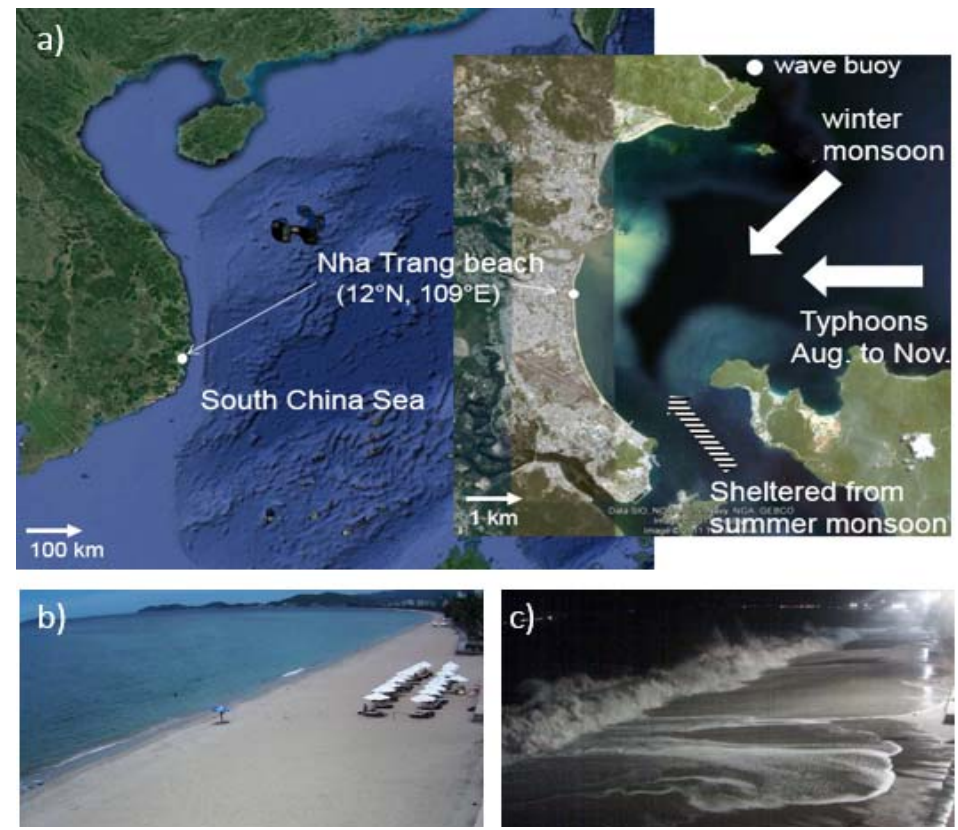

Figure 1. Study site, (a) Nha Trang each, Vietnam, facing the South China Sea. Images from the video system during (b) calm summer season and (c) Cat. 5 Haiyan typhoon.

From its orientation, Nha Trang region is mainly sheltered from summer monsoon which consists in very calm conditions. It can be considered that this stretch of coast is under the influence of winter monsoons and typhoons only [26,27].

\section{Methods and Data}

A video station was installed in May 2013 [26] in the central part of Nha Trang Bay, is considered far enough from the influence of the edges of the bay and is predominantly influenced by cross-shore rather than by longshore dynamics $[27,28]$. Hydrodynamic (waves, currents, tides) and morphology (intertidal and submerged bathymetry and shoreline) can be extracted from secondary images, timestack, and average images $[27,29]$. In this study, the shoreline was extracted manually at a single cross-shore section of the beach. It is estimated as the video-based average between maximum and minimum runup excursions over 15-min images and during daylight and night hours. Hourly tidal modulation of the shoreline location was averaged out using daily means. Wave fields were extracted from ERA-interim global reanalysis provided by the European Centre for Medium-Range Weather Forecasts (resolution of $0.5^{\circ}$, every $6 \mathrm{~h}$ [30]) at the closest node off Nha Trang, and validated over a two month period using a local wave gauge. This validation was successful (coefficient of determination $\mathrm{R}^{2}=0.87, \mathrm{RMSE}=0.26 \mathrm{~m}$ ) down to event scale, which made it possible to extend our study over a full annual period, from 1 August 2013 to 1 August 2014. The period starts from summer monsoon conditions until October, and then winter monsoon lasts until April when a new summer monsoon begins.

Observations of waves and shoreline changes were used to calibrate the parametrical model of equilibrium shoreline position ShoreFor [2,31] accounting for cross-shore transport processes. This model was chosen as it was applied successfully at various sites for predicting the daily to seasonal shoreline response to waves compared to other models more dedicated to long-term interannual evolution [32]. This one-dimensional shoreline prediction model has the form

$$
\frac{d x}{d t}=b+c\left(F^{+}+r F^{-}\right)
$$


where $b$ and $c$ are calibrated coefficients, $r$ the ratio between erosive and accretive shoreline change, and $F^{ \pm}$is the shoreline forcing, which depends on disequilibrium with anteceding wave conditions

$$
F^{ \pm}=P^{0.5}\left(\Omega_{e q}-\Omega\right)
$$

where $P$ is wave power $\left(\propto H s^{2} T p\right)$, with $H s$ and $T p$ as the deep water significant wave height and peak period, $\Omega$ and $\Omega_{\ell q}$ are the instant and time-varying dimensionless fall velocity such as

$$
\Omega_{e q}=\left[\sum_{i=1}^{2 \phi} \Omega_{e q} 10^{-i / \phi}\right]
$$

with $\Omega$ defined as $\Omega=H_{s} / w T_{p}$, where w is the settling velocity and is a function of the site-specific median grain size $\left(D_{50}\right)$. In Equation (3), $i$ is the day prior to present, $\phi$ the number of past days where the decaying exponential function reaches $10 \%$ (more details in $[2,14]$ ).

\section{Results}

The offshore wave forcing for the one year study period is presented in Figure 2a. The southeast coast of Vietnam is partly sheltered from summer monsoon low-energy wind-waves ( $H s<1 \mathrm{~m}, \mathrm{Tp}<4 \mathrm{~s})$. The winter season presents more energetic swell ( $H s \sim 1.7 \mathrm{~m}, \mathrm{Tp}=7-8 \mathrm{~s})$ and larger variability, with largest values ( $H s \sim 3 \mathrm{~m}, T p=10 \mathrm{~s}$ ) during monsoon events. Waves during typhoon events have similar magnitude but shorter duration ( $<3$ days). The shoreline (Figure $2 a$ ) is stable or even slightly in accretion till the end of summer monsoon in October, and then begins an erosive phase during winter monsoon until February when it reaches its most landward location, before migrating seaward again.
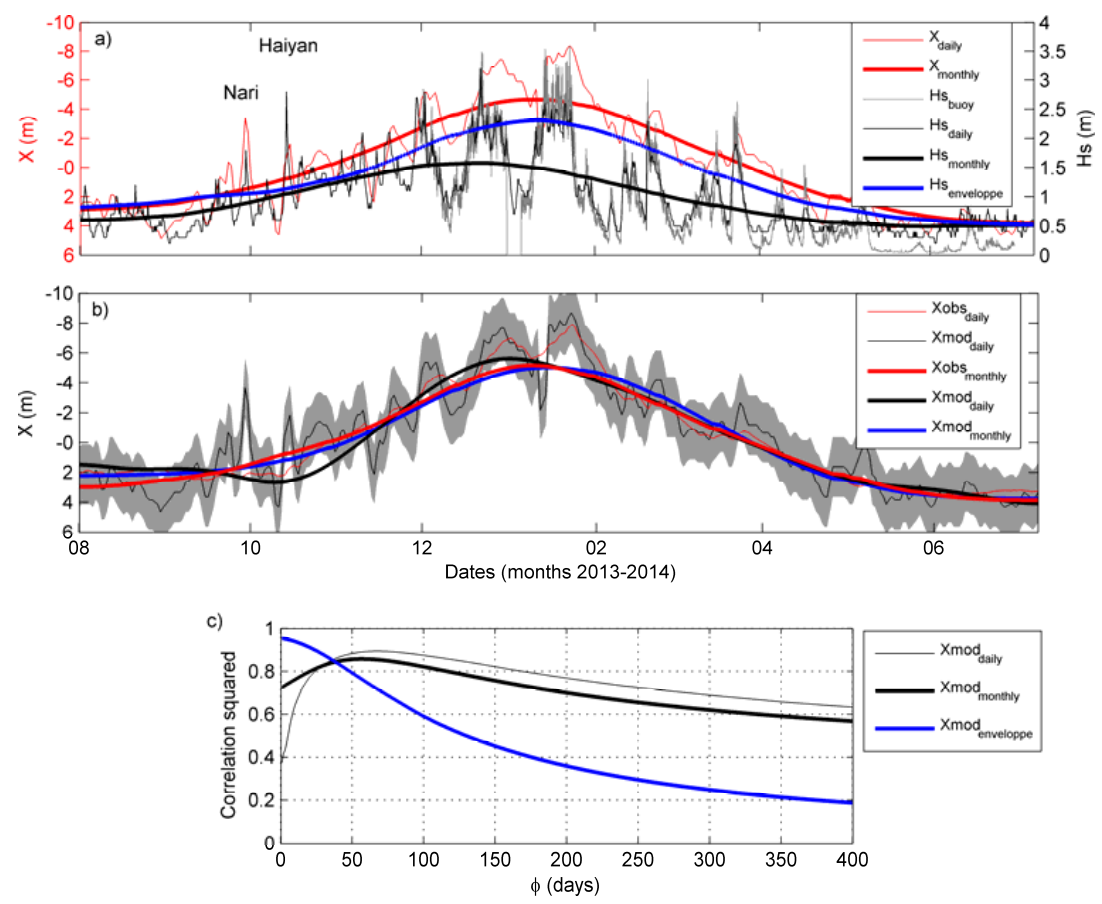

Figure 2. (a) Video-derived shoreline location $X$ (red), wave height Hs from Era-Interim (black) and from buoy (gray) off Nha Trang, with the monthly envelope of intra-seasonal Hs (from 3 to 30 days) in blue. (b) Results from the shoreline equilibrium model ShoreFor (black, with uncertainty as shaded area), compared with the observed daily shoreline position (red) and in (c) the respective correlations squared for different $\phi$ values. In panels $a, b$, negative and positive $X$ values stand for erosion and accretion from the mean, respectively. In $\mathrm{a}-\mathrm{c}$, thin and thick lines are daily and monthly data respectively. 
This seasonal pattern (duration $>30$ days) hides important intra-seasonal (or synoptic scale, i.e., winter monsoon events) variability with shoreline variations reaching $10 \mathrm{~m}$ during typhoon events and during long-lasting winter-monsoon events with durations from three days to three weeks. Even though the magnitude of shoreline retreat of these events is similar, Figure 2a shows that monsoon events have a more persistent impact with longer recovery (i.e., 10 to 20 days) than typhoons which takes a few days at most (sometimes within less than a day). While typhoon events were frequent at the beginning of the winter season, from October to December 2013, the magnitude of monsoon events increased and peaked in January to February of 2014. This coincided with already decreasing monthly-mean wave height but, surprisingly, the monthly-mean shoreline still eroded.

To investigate this two-month lag between monthly-mean waves and shoreline, the empirical shoreline equilibrium model ShoreFor (Equation (1)) was applied on daily wave and shoreline data. In Figure $2 \mathrm{~b}$ the model shows good skills $\left(\mathrm{R}^{2}=0.8, \mathrm{RMS}=1.2 \mathrm{~m}\right)$ at intra-seasonal (larger than three days) and seasonal scales but miss short-lived storm impacts. The best correlation appears for a lag $\phi$ of 50 days (Figure 2c), which is much larger than the actual morphological response time of a few days observed at this beach. To investigate this point further, the model was forced with monthly-averaged waves and with the monthly envelop of intra-seasonal events (Figure $2 b$ ). The latter is done by means of the Hilbert transform, already applied successfully to study wave groupiness [33,34], $\left|H s^{h f}(t)+\mathrm{H}\left\{H s^{h f}(t)\right\}\right|^{l f}$ where $H$ denotes the Hilbert transform operator and I If a low-pass filter operator, taking 30 days as the cutoff period separating short term $(h f)$ and monthly $(l f)$ timescales. Both monthly estimates well predict the seasonal shoreline behavior (Figure 2b), although that using the envelope gives more accuracy $\left(R^{2}=0.8\right.$ and $R^{2}=0.9, R M S=0.5$ and $R M S=0.3 \mathrm{~m}$ for monthly-averaged and envelope cases, respectively). Interestingly, the main difference rises from $\phi$ value in Figure 2c, which is similar (52 days) for monthly-averaged and daily data, but 0 for the envelope, indicating that the shoreline is in phase with the monthly envelope of energetic intra-seasonal events. Therefore, the shoreline is in better equilibrium with wave intra-seasonal events than monthly mean wave energy.

\section{Discussion}

One of the most striking points of this study is the wave energy provided by monsoon events and their dominant role on shoreline evolution. In contrast, while typhoons have large ephemeral impacts, our results show that the shoreline recovers rapidly. There is no evidence for a persistent influence, as suggested for short-lived storms by [35] and [36]. This is confirmed here using the ShoreFor model that presents good skills at predicting intra-seasonal and seasonal scales but poorly describes short-term typhoon-induced dynamics (see Figure 2b, October to November). Recurrence of typhoons is more than 10 days so that they can be considered isolated and without cumulative effect [5]. Winter monsoon events have impacts of similar magnitude to typhoons but with longer recovery, which is close to their observed recurrence period. Therefore, they can be considered as a sequence, as the beach cannot fully recover between events and is constantly moving towards a high energetic equilibrium. Note that the ratio of erosion and accretion rates for typhoons is nearly constant over time, but not so for winter monsoons: while the erosion rate is constant, the accretion rate decreases after each new event. This result highlights the importance of the wave event duration, to the extent that the erosive potential will be satisfied only if the event lasts the necessary time for the beach to establish a new equilibrium [6]. Thus for short-lived typhoons, the full erosion potential is not achieved. Despite the significant shoreline retreat, the beach profile is likely to be far from a new equilibrium. As a consequence, the shoreline recovery to its previous state (and shoreline position) occurs within a few days and does not affect longer term evolution [37]. On the other hand, winter monsoon events have enough duration to achieve their full erosion potential, thus modifying the beach to a fully new equilibrium. The return of the shoreline to its previous position takes longer, leaving the beach more vulnerable and for longer. 
It was previously observed that Nha Trang's embayed beach has a seasonal rotation with modulation of waves incidence [27], from northward summer to winter southward transport: the north end of the beach enlarges in summer and erodes in winter, the center of rotation being localized in the central part of the beach [38]. It is noteworthy that, even if summer monsoon has only a weak influence compared to the energetic winter monsoon, locally generated wind-waves induce this northward transport [26]. The shoreline at the central part of the beach close to the video system mainly experiences translation due to cross-shore dynamics and is rather dominated by event scale. This is similar to what has been observed elsewhere [39] where rotation and translation of the shoreline were quantified separately.

A main outcome of this study is the long lag (50-60 days) observed between monthly waves and shoreline location, while the envelope (Hilbert transform) of intra-seasonal monsoon events is in closer phase with the shoreline. This suggests that, contrarily to shoreline equilibrium model paradigms [2,13], the Nha Trang shoreline is actually in equilibrium with energetic wave conditions. This is in line with observations by [15] at low-energy environments where the beach is assumed to be in equilibrium with previous energetic wave events rather than with current conditions. The beach is considered inactive the rest of the time. Here, it is the particularly long duration of winter monsoon events that presumably drives most of the shoreline changes, with very gentle wave conditions in between which limit the recovery potential, as observed elsewhere by [10]. In this sense, the phase-lag observed here between seasonal means and the intra-seasonal envelope is crucial for shoreline equilibrium.

\section{Conclusions}

In this paper, we addressed the shoreline evolution of the tropical Nha Trang beach, Vietnam, over the particularly active 2013-2014 season. Our results show for the first time that long-lasting (3-10 days) monsoon events have more persistent impact than typhoons (less than 3 days), of similar amplitude but rather transient with fast recovery. The ShoreFor shoreline equilibrium model shows good skills in predicting seasonal shoreline behavior. The seasonal shoreline appears driven by the intra-seasonal event envelope (from Hilbert transform) rather than monthly-averaged waves. Finally, this paper suggests that the interplay between intra-seasonal event intensity and duration, on the one hand, and recovery conditions, on the other, might be of key significance. Therefore, their evolution in a variable or changing climate should be considered.

Acknowledgments: This work was supported by Vietnamese grant (MOST2/216/QD/BKHCN-No2994) and French ANR project COASTVAR (ANR-14-ASTR-0019). We acknowledge use of the ECMWF ERAInterim dataset (www.ECMWF.Int/research/Era). DHT PhD supported by ARTS-IRD program.

Author Contributions: Rafael Almar, Patrick Marchesiello, Nguyen Trung Viet and Luis Pedro Almeida designed the project and conducted analyses. Duong Hai Thuan analyzed the video images and Hitoshi Tanaka provided expertise on shoreline dynamics. All authors wrote the paper.

Conflicts of Interest: The authors declare no conflict of interest.

\section{References}

1. Ashton, A.D.; Evans, R.L.; Donnelly, J.P. Discussion of the Potential Impacts of Climate Change on the Shorelines of the Northeastern USA. Mitig. Adapt. Strateg. Glob. Chang. 2008, 13, 719-743. [CrossRef]

2. Davidson, M.A.; Splinter, K.D.; Turner, I.L. A simple equilibrium model for predicting shoreline change. Coast. Eng. 2013, 73, 191-202. [CrossRef]

3. Cooper, J.A.G.; Pilkey, O.H. Sea-level rise and shoreline retreat: Time to abandon the Bruun Rule. Glob. Planet. Chang. 2004, 43, 157-171. [CrossRef]

4. Anderson, T.R.; Frazer, L.N.; Fletcher, C.H. Transient and persistent shoreline change from a storm. Geophys. Res. Lett. 2010, 37. [CrossRef]

5. Ranasinghe, R.; Holman, R.; de Schipper, M.A.; Lippmann, T.; Wehof, J.; Minh Duong, T.; Roelvink, D.; Stive, M.J.F. Quantification of nearshore morphological recovery time scales using Argus video imaging: Palm Beach, Sydney and Duck, NC. Coast. Eng. Proc. 2012, 1, 24. 
6. Kriebel, D.L.; Dean, R.G. Convolution method for time dependent beach profile response. J. Waterw. Port. Coast. Ocean Eng. 1993, 119, 204-226. [CrossRef]

7. Frazer, L.N.; Anderson, T.R.; Fletcher, C.H. Modeling storms improves estimates of long-term shoreline change. Geophys. Res. Lett. 2009, 36. [CrossRef]

8. Ferreira, Ó. Storm groups versus extreme single storms: Predicted erosion and management consequences. J. Coast. Res. 2005, 21, 221-227.

9. Coco, G.; Senechal, N.; Rejas, A.; Bryan, K.R.; Capo, S.; Parisot, J.P.; Brown, J.A.; MacMahan, J.H.M. Beach response to a sequence of extreme storms. Geomorphology 2014, 204, 493-501. [CrossRef]

10. Karunarathna, H.; Pender, D.; Ranasinghe, R.; Short, A.D.; Reeve, D.E. The effects of storm clustering on beach profile variability. Mar. Geo. 2014, 348, 103-112. [CrossRef]

11. Splinter, K.D.; Carley, J.T.; Golshani, A.; Tomlinson, R. A relationship to describe the cumulative impact of storm clusters on beach erosion. Coast. Eng. 2014, 83, 49-55. [CrossRef]

12. Masselink, G.; Scott, T.; Poate, T.; Russell, P.; Davidson, M.; Conley, D. The extreme 2013/14 winter storms: Hydrodynamic forcing and coastal response along the southwest coast of England. Earth Surf. Proc. Landf. 2016, 41, 378-391. [CrossRef]

13. Yates, M.L.; Guza, R.T.; O'Reilly, W.C. Equilibrium shoreline response: Observations and modeling. Geophys. Res. 2009, 114. [CrossRef]

14. Splinter, K.D.; Turner, I.L.; Davidson, M.A.; Barnard, P.; Castelle, B.; Oltman-Shay, J. A generalized equilibrium model for predicting daily to interannual shoreline response. J. Geophys. Res. Earth Surf. 2014, 119, 1936-1958. [CrossRef]

15. Jackson, N.L.; Nordstrom, K.F.; Eliot, I.; Masselink, G. "Low energy" sandy beaches in marine and estuarine environments: A review. Geomorphology 2002, 48, 147-162. [CrossRef]

16. Chen, S.S.; Curcic, M. Ocean surface waves in Hurricane Ike (2008) and Superstorm Sandy (2012): Coupled modeling and observations. Ocean Mod. 2016, 103, 161-176. [CrossRef]

17. Chang, C.-P.; Wang, Z.; Hendon, H. The Asian Monsoon; Springer: Heidelberg, Germany, 2006; pp. 89-128.

18. Wu, M.C.; Chan, J.C.L. Surface features of winter monsoon surges over South China. Mon. Wea. Rev. 1995, 123, 662-680. [CrossRef]

19. Camargo, S.J.; Robertson, A.W.; Gaffney, S.J.; Smyth, P.; Ghil, M. Cluster analysis of typhoon tracks, Part I: General properties. J. Clim. 2007, 20, 3635-3653. [CrossRef]

20. Nicholls, R.J.; Hoozemans, F.M.; Marchand, M. Increasing flood risk and wetland losses due to global sea-level rise: Regional and global analyses. In Global Environmental Change; Elsevier: Amsterdam, The Netherlands, 1999; Volume 9, pp. 69-87.

21. Chan, J.C.L. Tropical cyclone activity in the northwest Pacific in relation to El Niño/Southern Oscillation phenomenon. Mon. Weather Rev. 1985, 113, 599-606. [CrossRef]

22. Nakamura, T.; Yamazaki, K.; Iwamoto, K.; Honda, M.; Miyoshi, Y.; Ogawa, Y.; Tomikawa, Y.; Ukita, J. The stratospheric pathway for Arctic impacts on midlatitude climate. Geophys. Res. Lett. 2016, 43, 3494-3501. [CrossRef]

23. Nakamura, R.; Shibayama, T.; Esteban, M.; Iwamoto, T. Future typhoon and storm surges under different global warming scenarios: Case study of typhoon Haiyan (2013). Nat. Hazards 2016, 82, 1645-1681. [CrossRef]

24. Chu, P.C.; Qi, Y.; Chen, Y.; Shi, P.; Mao, Q. South China Sea wind- wave characteristics. Part I: validation of Wavewatch-III using TOPEX/Poseidon data. J. Atmos. Ocean Technol. 2004, 21, 1718-1733. [CrossRef]

25. Mirzaei, A.; Tangang, F.; Juneng, L.; Mustapha, M. A.; Husain, M. L.; Akhir, M. F. Wave climate simulation for southern region of the South China Sea. Ocean Dyn. 2013, 63, 961-977. [CrossRef]

26. Lefebvre, J.-P.; Almar, R.; Viet, N.T.; Uu, D.V.; Thuan, D.H.; Binh, L.T.; Ibaceta, R.; Duc, N.V. Contribution of swash processes generated by low energy wind waves in the recovery of a beach impacted by extreme events: Nha Trang, Vietnam. J. Coast. Res. 2014, 70, 663-668. [CrossRef]

27. Duong, H.T.; Binh, L.T.; Viet, N.T.; Hanh, K.D.; Almar, R.; Marchesiello, P. Typhoon impact and shoreline recovery from continuous video monitoring: a case study from Nha Trang beach, Vietnam. Proceedings of the 14th International Coastal Symposium (Sydney, Australia). J. Coast. Res. 2016, 75, 263-267.

28. Almeida, L.P.; Almar, R.; Marchesiello, P.; Blenkinsopp, C.; Martins, K.; Sénéchal, N.; Floc’H, F.; Bergsma, E.; Benshila, R.; Caulet, C.; et al. Swash zone dynamics of a reflective beach with a low tide terrace. Mar. Geol. 2017, submitted for publication. 
29. Abessolo, O.G.; Almar, R.; Kestenare, E.; Bahini, A.; Houngue, G.H.; Jouanno, J.; Du, P.Y.; Castelle, B.; Melet, A.; Messignac, B.; et al. Potential of video cameras in assessing event and seasonal coastline behaviour: Grand Popo, Benin (Gulf of Guinea). J. Coast. Res. 2016, 75, 442-446. [CrossRef]

30. Dee, D.P.; Uppala, S.M.; Simmons, A.J.; Berrisford, P.; Poli, P.; Kobayashi, S.; Andrae, U.; Balsamo, G.; Bauer, P.; Bechtold, P. The ERA-Interim reanalysis: Configuration and performance of the data assimilation system. Q. J. R. Meteorol. Soc. 2011, 137, 553-597. [CrossRef]

31. Davidson, M.A.; Turner, I.L. A behavioral template beach profile model for predicting seasonal to interannual shoreline. J. Geophys. Res. 2009, 114, F01020. [CrossRef]

32. Ruggiero, P.; Buijsman, M.; Kaminsky, G.M.; Gelfenbaum, G. Modeling the effects of wave climate and sediment supply variability on large-scale shoreline change. Mar. Geol. 2010, 273, 127-140.

33. Veltcheva, A.D. Wave and group transformation by a Hilbert spectrum. Coast. Eng. J. 2002, 44, $283-300$. [CrossRef]

34. Ortega, J.; Smith, G.H. Hilbert-Huang transform analysis of storm waves. Appl. Ocean Res. 2009, 31, $212-219$. [CrossRef]

35. Douglas, B.C.; Crowell, M. Long-Term Shoreline Position Pre diction and Error Propagation. J. Coast. Res. 2000, 16, 145-152.

36. Zhang, K.; Douglas, B.C.; Leatherman, S.P. Do Storms Cause Long-Term Beach Erosion along the U.S. East Barrier Coast? J. Geol. 2002, 110, 493-502. [CrossRef]

37. Hansen, J.E.; Barnard, P.L. Sub-weekly to interannual variability of a high-energy shoreline. Coast. Eng. 2010, 57, 959-972. [CrossRef]

38. Thanh, T.M.; Tanaka, H.; Viet, N.T.; Mitobe, Y.; Hoang, V.C. Evaluation of longshore sendiment transport on Nha Trang coast considering influence of Northeast monsoon waves. J. Jpn. Soc. Civ. Eng. 2015, $71,1681-1686$.

39. Turki, I.; Medina, R.; Gonzalez, M.; Coco, G. Natural variability of shoreline position: Observations at three pocket beaches. Mar. Geol. 2013, 338, 76-89. [CrossRef]

(C) 2017 by the authors. Licensee MDPI, Basel, Switzerland. This article is an open access article distributed under the terms and conditions of the Creative Commons Attribution (CC BY) license (http:/ / creativecommons.org/licenses/by/4.0/). 